\title{
Originals
}

\section{The effect of low-dose dopamine on renal haemodynamics in patients with Type 1 (insulin-dependent) diabetes does not differ from normal individuals}

\author{
P. M.ter Wee, E.van Ballegooie, J. B. Rosman, S. Meijer and A.J. M. Donker* \\ Departments of Medicine, State University Hospital Groningen and *Free University Hospital Amsterdam, The Netherlands
}

\begin{abstract}
Summary. It is well known that patients with Type 1 (insulindependent) diabetes exhibit both increased glomerular filtration rate and effective renal plasma flow, which can be found even when these patients are well controlled. Usually this is attributed to a decrease in renal vascular resistance and/or to enlarged kidney size and glomerular volume. Among the factors which govern glomerular filtration rate, renal plasma flow is most important. Renal plasma flow increases if renal vascular resistance decreases. The latter might exist in insulin-dependent diabetes mellitus because of either a predominantly afferent or a predominantly efferent vasodilatation. Dopamine is an agent which causes predominantly efferent vasodilatation. Therefore, the effects of infusing a low dose of dopa-
\end{abstract}

mine on glomerular filtration rate and effective renal plasma flow in 12 well-controlled patients with Type 1 (insulin-dependent) diabetes and 28 healthy volunteers were compared to investigate whether the increased glomerular filtration rate in Type 1 diabetes is caused by an efferent vasodilatation. The median increase in glomerular filtration rate during dopamine infusion amounted to $13.0 \%$ in diabetic patients and $12.5 \%$ in healthy control subjects (n. s.). It is concluded that the elevated glomerular filtration rate in well-controlled Type 1 diabetes is not caused by a predominantly efferent vasodilatation.

Key words: Type 1 diabetes, glomerular filtration rate, effective renal plasma flow, renal vascular resistance, dopamine.
In Type 1 (insulin-dependent) diabetes, a supernormal glomerular filtration rate (GFR) and effective renal plasma flow (ERPF) have been well established, especially during poor metabolic control [1-3]. In obesity and acromegaly, conditions also characterized by a supernormal renal function $[4,5]$, high GFR has been attributed to an expanded extracellular fluid volume [6, 7]. In Type 1 diabetes, however, it has been found that the relation between extracellular fluid volume and body weight (or body surface area) is normal [8]. This indicates that the high GFR in Type 1 diabetes reflects a real hyperfiltration. Recently, it has been suggested that such a hyperfiltration initiates the process of glomerulosclerosis $[9,10]$.

A low dose of dopamine can be used to increase ERPF and GFR [11-13]. As ERPF increases more than GFR during dopamine infusion, the filtration fraction (FF) falls. Therefore, it has been concluded that the dopamine-induced decrease in renal vascular resistance [14] is obtained by predominantly efferent vasodilatation [13]. To investigate whether efferent vasodilatation is an important factor in the elevated GFR in Type 1 diabetes, the effects of dopamine infusion on GFR, ERPF and FF in twelve patients with this disorder were compared with the effects of low-dose dopamine on those parameters in 28 healthy control subjects.

\section{Subjects and methods}

In 12 non-obese Type 1 diabetic patients (four male and eight female), renal function was measured before and during dopamine infusion. The median age was 25.5 years and the median duration of diabetes was 7.5 years (Table 1 ). All had developed diabetes before age 30 . Cpeptide levels were below $0.1 \mathrm{nmol} / 1$ after stimulation with glucagon. None had hypertension or signs of clinical nephropathy (i. e. proteinuria $<0.5 \mathrm{~g} / 24 \mathrm{~h}$ and creatinine clearance $\geqslant 80 \mathrm{ml} / \mathrm{min}$ ), and there existed no or only mild background retinopathy. All were treated with intensive insulin therapy, i.e. multiple insulin injections and frequent home blood glucose monitoring with reagent strips, with adjustment of the insulin dose accordingly. (Near) normoglycaemia (3-10 mmol/ 1) was the goal for all patients.

Supine position GFR was measured with ${ }^{125}$ I-iothalamate and ERPF with ${ }^{131}$ I-hippurate, which were simultaneously infused. Iothalamate is a satisfactory substitute for inulin [15]. The clearances of $p$ aminohippurate and ${ }^{131}$ I-hippurate are both representative of renal plasma flow when the difference in extraction is taken into account $[15,16]$. The radiopharmaceuticals were infused at a constant rate af ter a priming dose was given. After an equilibration period of $1.5 \mathrm{~h}$, two 2 -h clearances were determined using the formula $\mathrm{U} \times \mathrm{V} / 120 \times \mathrm{P}$ [16]. At the end of this standard procedure, dopamine was infused at a dose of $1.5-2.0 \mu \mathrm{g} \cdot \mathrm{kg}^{-1} \cdot \mathrm{min}^{-1}$ for $2 \mathrm{~h}$ (Braun Unita II pump, Melsungen, FRG). GFR and ERPF during these $2 \mathrm{~h}$ were compared with the GFR and ERPF just before dopamine infusion (also measured over a 2 -h period). The coefficients of variation of the determinations are $\leqslant 2.2 \%$ for GFR, and $\leqslant 5.0 \%$ for ERPF [16]. FF was defined as the ratio GFR:ERPF (normal value in our laboratory amounts to $0.22-0.28$ ). During the procedure a diuresis of at least $100 \mathrm{ml} / \mathrm{h}$ was pursued by oral administration of fluids. 
Table 1. Sex, age (years), duration of diabetes (years), mean $\mathrm{HbA}_{1}^{\mathrm{a}}$ (\%) during the control year, and mean 24-h blood glucose (mmol/l) during the control year in twelve patients with Type 1 (insulin-dependent) diabetes

\begin{tabular}{lllll}
\hline Sex & $\begin{array}{l}\text { Age } \\
\text { (years) }\end{array}$ & $\begin{array}{l}\text { Duration } \\
\text { (years) }\end{array}$ & $\begin{array}{l}\text { Mean HbA } \\
(\%) \\
\text { (SEM) }\end{array}$ & $\begin{array}{l}\text { Mean glucose } \\
(\%) \\
\text { (SEM) }\end{array}$ \\
\hline $\mathrm{F}$ & 29 & 12 & $7.0(0.3)$ & $5.4(0.3)$ \\
$\mathrm{F}$ & 28 & 13 & $7.0(0.2)$ & $6.4(0.3)$ \\
$\mathrm{F}$ & 23 & 9 & $6.4(0.2)$ & $6.0(0.7)$ \\
$\mathrm{F}$ & 21 & 4 & $7.8(0.2)$ & $8.7(0.4)$ \\
$\mathrm{F}$ & 27 & 2 & $7.4(0.3)$ & $8.1(0.9)$ \\
$\mathrm{F}$ & 23 & 3 & $8.0(0.3)$ & $7.7(0.9)$ \\
$\mathrm{F}$ & 32 & 4 & $7.9(0.3)$ & $9.2(0.5)$ \\
$\mathrm{F}$ & 24 & 9 & $7.9(0.3)$ & $8.8(0.4)$ \\
$\mathrm{M}$ & 32 & 6 & $8.0(0.4)$ & $7.5(0.6)$ \\
$\mathrm{M}$ & 23 & 4 & $7.7(0.4)$ & $7.0(0.6)$ \\
$\mathrm{M}$ & 43 & 13 & $7.9(0.4)$ & $8.2(0.3)$ \\
$\mathrm{M}$ & 24 & 10 & $6.9(0.3)$ & $7.3(0.5)$ \\
median & 25.5 & 7.5 & 7.8 & 7.6 \\
mean & 27.4 & 7.4 & 7.5 & 7.5 \\
& & SEM & 0.2 & 0.4 \\
\hline
\end{tabular}

a Normal range $6.0-8.5 \%$

Table 2. GFR $\quad\left(\mathrm{ml} \cdot \mathrm{min}^{-1} \cdot\left(1.73 \mathrm{~m}^{2}\right)^{-1}\right), \quad$ ERPF $\quad\left(\mathrm{ml} \cdot \mathrm{min}^{-1}\right.$. $\left.\left(1.73 \mathrm{~m}^{2}\right)^{-1}\right)$ and $\mathrm{FF}$ before (B) and during dopamine infusion (D) in 12 Type 1 diabetic patients at the beginning of the study

\begin{tabular}{lccl}
\hline & GFR & ERPF & FF \\
\hline B Median & 134.5 & 561.5 & 0.24 \\
Mean & 130.9 & 551.6 & 0.24 \\
SEM & 4.9 & 18.8 & 0.006 \\
D Median & $142.5^{*}$ & $684.0^{*}$ & $0.22^{*}$ \\
Mean & 146.7 & 697.5 & 0.21 \\
SEM & 6.3 & 23.9 & 0.007 \\
\hline
\end{tabular}

${ }^{*} p<0.01$

Table 3. The effect of low-dose dopamine (D) on baseline (BL) GFR $\left(\mathrm{ml} \cdot \mathrm{min}^{-1} \cdot\left(1.73 \mathrm{~m}^{2}\right)^{-1}\right)$ in 28 control subjects (I) and in 12 Type 1 diabetic patients (II)

\begin{tabular}{|c|c|c|c|c|c|}
\hline & & BL & D & $\begin{array}{l}\Delta \mathrm{GFR} \\
\mathrm{ml} / \mathrm{min}\end{array}$ & $\begin{array}{l}\triangle \mathrm{GFR} \\
\%\end{array}$ \\
\hline \multirow[t]{3}{*}{ I } & Median & 109.0 & $124.5^{*}$ & 11.0 & 12.5 \\
\hline & Mean & 111.6 & 125.2 & 13.6 & 12.2 \\
\hline & SEM & 3.3 & 3.5 & 2.0 & 1.9 \\
\hline \multirow[t]{3}{*}{ II } & Median & 131.0 & $147.5^{*}$ & 14.0 & 13.0 \\
\hline & Mean & 128.6 & 142.7 & 14.1 & 11.0 \\
\hline & SEM & 5.9 & 5.4 & 2.4 & 1.9 \\
\hline
\end{tabular}

$* p<0.01$

To exclude effects of poor metabolic regulation, the renal function studies, including the effect of low-dose dopamine, were repeated after one year of careful glycaemic control. The latter consisted of obtaining 24-h blood glucose profiles every $2-4$ weeks by measuring blood glucose in finger prick samples which were taken at $03.00,07.00$ (fasting), $09.00,11.00,14.00,17.00,19.00$ and $24.00 \mathrm{~h}$. The samples were stored in small plastic cups for measurement in the laboratory (Auto-analyzer II, Technikon, Tarrytown, NY, USA). All the curves obtained in this way during the control year were used to calculate an individual mean 24-h blood glucose value during the control year. Furthermore, glycosylated haemoglobin $\left(\mathrm{HbA}_{1}\right)$ was measured every two months by the colorimetric method of Flückiger and Winterhalter [17]. Thus, individual mean $\mathrm{HbA}_{1}$ during the control year was calculated. Finally, all patients were seen at the diabetes outpatient clinic every four weeks.

The control group consisted of 22 male and six female volunteers, with a median age not significantly different from the median age of the patient group ( 31.5 years, range 19-48).

The study was approved by the medical ethics committee of the University Hospital Groningen. All individuals gave verbal consent for the infusion of dopamine.

Heart rate (HR) and blood pressure were recorded at intervals of 15 min during dopamine infusion and the preceding 2-h period. Mean arterial pressure (MAP) was calculated by adding one-third of the pulse pressure to the diastolic blood pressure.

\section{Statistical analysis}

Statistical analysis was performed on median values, since we considered our data not normally distributed. Wilcoxon rank sum tests on paired and unpaired samples were used. A probability level of $p<$ 0.05 was chosen as the level of significance. Though the control group contained significantly more males than females $(p<0.05)$, no subdivision between males and females was made; in neither the control group nor the patient group did baseline GFR, baseline ERPF, baseline FF, and dopamine-induced changes in GFR, ERPF and FF in males differ from those in females.

\section{Results}

In Table 1 the individual data on sex, age, duration of diabetes, mean $\mathrm{HbA}_{1}$ and mean 24-h blood glucose of the 12 diabetic patients are listed. The median value of the individual mean $\mathrm{HbA}_{1}$ during the control year was $7.8 \%$ (range 6.4-8.0; normal range 6.0-8.5\%). The median value of the individual mean $24-\mathrm{h}$ blood glucose value during the control year was $7.6 \mathrm{mmol} / 1$ (range 5.4-9.2). From these two findings it was concluded that metabolic control during the control year was rather good. None of the patients developed signs of clinical nephropathy or hypertension during the control year.

At the beginning of the control year, median GFR was $134.5 \mathrm{ml} \cdot \mathrm{min}^{-1} \cdot\left(1.73 \mathrm{~m}^{2}\right)^{-1}$ (range $\left.95-161\right)$, median ERPF $561.5 \mathrm{ml} \cdot \mathrm{min}^{-1} \cdot\left(1.73 \mathrm{~m}^{2}\right)^{-1}$ (range $\left.383-635\right)$ and median FF 0.24 (range $0.20-0.27$ ), as shown in Table 2.

After the control year, median GFR in Type 1 diabetic patients had not significantly changed, and was $131.0 \mathrm{ml} \cdot \mathrm{min}^{-1} \cdot\left(1.73 \mathrm{~m}^{2}\right)^{-1}$ (range $\left.86-170\right)$. This was significantly higher when compared with the median GFR in healthy control subjects $\left(109 \mathrm{ml} \cdot \mathrm{min}^{-1}\right.$. $\left(1.73 \mathrm{~m}^{2}\right)^{-1}$; range $\left.90-145 ; p<0.02\right)$. Median ERPF was $538 \mathrm{ml} \cdot \mathrm{min}^{-1} \cdot\left(1.73 \mathrm{~m}^{2}\right)^{-1}$ (range $317-613$ ) in diabetic patients and $443 \mathrm{ml} \cdot \mathrm{min}^{-1} \cdot\left(1.73 \mathrm{~m}^{2}\right)^{-1}$ (range $\left.327-679\right)$ in control subjects $(p<0.02)$. In both diabetic patients and control subjects GFR increased significantly during the infusion of low-dose dopamine (Table 3). Interestingly, however, there was no significant difference in dopamine-induced increase in GFR between the two groups. Similar comparisons held true for ERPF 
Table 4. The effect of low-dose dopamine (D) on baseline (BL) ERPF $\left(\mathrm{ml} \cdot \mathrm{min}^{-1} \cdot\left(1.73 \mathrm{~m}^{2}\right)^{-1}\right)$, and FF in 28 control subjects (I) and in 12 Type 1 diabetic patients (II)

\begin{tabular}{lllllll}
\hline & \multicolumn{2}{c}{ ERPF } & & & FF \\
\cline { 2 - 3 } \cline { 6 - 6 } & BL & D & & BL & D \\
\hline I & Median & 443.0 & $622.5^{*}$ & & 0.25 & $0.20^{*}$ \\
& Mean & 461.3 & 628.8 & & 0.24 & 0.20 \\
& SEM & 15.3 & 20.1 & & 0.006 & 0.004 \\
II & Median & 538.0 & $694.0^{*}$ & & 0.24 & $0.21^{*}$ \\
& Mean & 530.8 & 669.8 & & 0.24 & 0.21 \\
& SEM & 22.1 & 30.4 & & 0.006 & 0.006 \\
\hline
\end{tabular}

${ }^{*} p<0.01$

(Table 4). FF fell in both diabetic patients and control subjects during dopamine infusion (Table 4).

Dopamine infusion did not affect HR or MAP significantly. Median HR was 72 beats per minute (bpm) in control subjects versus $76 \mathrm{bpm}$ during dopamine infusion. In Type 1 diabetic patients, median HR was $74 \mathrm{bpm}$ versus $80 \mathrm{bpm}$ during dopamine. Median values for MAP were 94 versus $92 \mathrm{mmHg}$ in control subjects, and 87 versus $87 \mathrm{mmHg}$ in diabetic patients.

\section{Discussion}

Increased kidney size with increased filtration surface area, high plasma levels of glucagon, growth hormone and non-specified other mediators, and poor metabolic control itself are the factors which have been implicated in the supernormal GFR and ERPF of Type 1 diabetic patients [18]. Especially during poor metabolic control, a very high GFR can be observed. The latter is most likely caused by a hyperglycaemia-induced change in renal haemodynamics [19]. The literature on the effect of long-term normoglycaemia on GFR and ERPF in Type 1 diabetic patients is contradictory. Recently, it was concluded that good metabolic control for one year normalizes GFR [20]. In another recent study, we also demonstrated that good metabolic control for a longer period decreases GFR [21]. In the present study, however, we found that GFR in the patient group was still increased when compared with the control group after one year of careful glycaemic control. This might indicate that our patients still were not well-controlled enough, or that, even during careful long term glycaemic control, renal vascular resistance is basically decreased in Type 1 diabetes [22]. Such a decrease in renal vascular resistance will exist in case of efferent vasodilatation, afferent vasodilatation or a generalized vasodilatation.

Infusion of a low dose of dopamine causes a predominantly efferent vasodilatation which is mediated by specific renal dopamine receptors and results in an increase in renal blood flow and GFR [13, 14, 23]. Administration of dopamine at a dose of $2.0 \mu \mathrm{g} \cdot \mathrm{kg}^{-1}$. $\min ^{-1}$ results in the highest increase in ERPF and GFR, although in some individuals ERPF and GFR can be increased slightly more by infusing dopamine at a rate of $4.0 \mu \mathrm{g} \cdot \mathrm{kg}^{-1} \cdot \mathrm{min}^{-1}$ (A. J. Smit, personal communication). The effect of dopamine on renal haemodynamics is most pronounced in healthy individuals [14]. In patients with IgA-glomerulopathy, GFR could not be improved if baseline GFR amounted to $73 \mathrm{ml} \cdot \mathrm{min}^{-1}$. $\left(1.73 \mathrm{~m}^{2}\right)^{-1}$ or less [12].

In the present study we found that the dopamine-induced changes in ERPF and GFR of normoglycaemic insulin-dependent diabetic patients did not differ from those observed in control subjects. This finding militates against a fall in renal vascular resistance caused by a predominantly efferent vasodilatation in Type 1 diabetes since a lesser effect of dopamine is expected in already existing efferent vasodilatation. The normal FF in our well-controlled diabetic patients is also in accord with this finding. Thus, factors other than efferent vasodilatation must be responsible for the hyperfiltration in Type 1 diabetes.

Recently, it was suggested that there exists an enhanced release of the liver hormone "glomerulopressin" in Type 1 diabetes which causes only afferent vasodilatation and, therefore, an increase in glomerular plasma flow and a rise in ultrafiltration pressure [24-26]. This results in an increased GFR with an unchanged or slightly elevated FF. An increased glomerular ultrafiltration pressure has been so demonstrated in diabetic rats [27].

The increase in GFR that can be observed during protein intake or glucagon infusion is also thought to be caused by an enhanced glomerulopressin release [24]. Indeed, we have shown that the infusion of amino acids in healthy individuals increases GFR (median value from 110 to $126 \mathrm{ml} \cdot \mathrm{min}^{-1} \cdot\left(1.73 \mathrm{~m}^{2}\right)^{-1}$ ) and ERPF (median value from 431 to $\left.543 \mathrm{ml} \cdot \mathrm{min}^{-1} \cdot\left(1.73 \mathrm{~m}^{2}\right)^{-1}\right)$ without affecting FF [28]. These values, obtained during amino acid infusion in normal individuals, are comparable with those found in the (near) normoglycaemic patients with Type 1 diabetes of the present study. Interestingly, Bosch et al. [22] found that a protein load did not influence GFR in Type 1 diabetic patients with normal to supernormal GFR. However, to confirm the hypothesis that in Type 1 diabetes a predominantly afferent vasodilatation exists due to, for instance, an enhanced glomerulopressin release, more detailed studies are warranted.

A general renal vasodilatation induced by the diabetic state as an explanation for increased ERPF and GFR is not excluded. However, if such a generalized vasodilatation (including the existence of efferent vasodilatation) exists, it seems contradictory that the effect of low-dose dopamine on renal haemodynamics in Type 1 diabetic patients did not differ from the effect observed in healthy volunteers. Finally, an increased kidney weight per se $[2,3,20]$ might explain the supernormal GFR and ERPF. An increased kidney weight 
has been found to be associated with a decreased renal vascular resistance in the mature growing rat which results in an increased renal plasma flow [29].

In conclusion, we found a supernormal GFR and ERPF in patients with Type 1 diabetes, even after a long period of fairly well-regulated metabolic control. The hyperfiltration seemed not to be caused by a decrease in renal vascular resistance on the base of efferent vasodilatation. A decreased renal vascular resistance caused by afferent vasodilatation and an increased kidney weight are remaining possibilities which might explain the supernormal ERPF and GFR in Type 1 diabetes.

Acknowledgements. This study was supported by the Dutch Kidney Foundation (Nier Stichting Nederland; grant C82-372). We thank Ms. A. Drent-Bremer for technical assistance, Ms. A. Koster-Veenstra for secretarial assistance, and the Department of Nuclear Medicine for the counting and computing facilities.

\section{References}

1. Fiaschi E, Grassi B, Andres G (1952) La funzione renale del diabete mellito. Rass Fisiop Clin Terap 24: 371-410

2. Mogensen CE, Andersen MJF (1975) Increased kidney size and glomerular filtration rate in untreated juvenile diabetes: normalization by insulin treatment. Diabetologia 11: 221-224

3. Christiansen JS, Gammelgaard J, Tronier B, Svendsen PA, Parving HH (1982) Kidney function and size in diabetics before and during initial insulin treatment. Kidney Int 21: 683-688

4. Stokholm KH, Brøchner-Mortensen J, Hoilund-Carlsen PF (1980) Increased glomerular filtration rate and adrenocortical function in obese women. Int J Obes 4: 57-63

5. Falkheden T, Sjögren B (1964) Extracellular fluid volume and renal function in pituitary insufficiency and acromegaly. Acta Endocrinol (Copenh) 46: 80-86

6. Brøchner-Mortensen J, Rickers H, Balslev I (1980) Renal function and body composition before and after intestinal bypass operation in obese patients. Scan J Lab Invest 40: 695-702

7. Ikkos D, Ljunggren H, Luft R (1956) Glomerular filtration rate and renal plasma flow in acromegaly. Acta Endocrinol (Copenh) 21: $226-236$

8. Brochner-Mortensen J, Ditzel J (1982) Glomerular filtration rate and extracellular fluid volume in insulin-dependent patients with diabetes mellitus. Kidney Int 21: 696-698

9. Hostetter TH, Olson JL, Rennke HG, Venkatachalam MA, Brenner BM (1981) Hyperfiltration in remnant nephrons: a potentially adverse response to renal ablation. Am J Physiol 241: F85-F93

10. Brenner BM (1983) Hemodynamically mediated glomerular injury and the progressive nature of kidney disease. Kidney Int 23 : $647-655$

11. Vlachoyannis J, Weismüller G, Schoeppe W (1976) Effects of dopamine on kidney function and on the adenyl cyclase phosphodiesterase system in man. Eur J Clin Invest 6: 131-137

12. Beukhof JR, ter Wee PM, Sluiter WJ, Donker AJM (1985) The effect of low dose dopamine on effective renal plasma flow and glomerular filtration rate in 32 patients with IgA-glomerulopathy. Am J Nephrol 5: 267-270
13. Chapman BJ, Horn NM, Munday KA, Robertson MJ (1980) The actions of dopamine and sulpiride on regional blood flow in the rat. J Physiol 298: 437-452

14. ter Wee PM, Smit AJ, Rosman JB, Sluiter WJ, Donker AJM (1986) The effect of intravenous infusion of a low-dose dopamine on renal function in normal individuals and in patients with renal disease. Am J Nephrol (in press)

15. Houwen B, Donker AJM, Woldring MG, Beekhuis $H$, van Zanten AK, Looyé A, van der Hem GK (1971) Simultaneous determination of glomerular filtration rate with ${ }^{125} \mathrm{I}$-iothalamate and effective renal plasma flow with ${ }^{131}$ I-hippuran. In: Dynamic studies with radioisotopes in medicine, IAEA, Vienna, $\mathrm{p} 331$

16. Donker AJM, van der Hem GK, Sluiter WJ, Beekhuis H (1977) A radioisotope method for simultaneous determination of the glomerular filtration rate and the effective renal plasma flow. Neth $J$ Med 20: 97-103

17. Flückiger R, Winterhalter KH (1976) In vitro synthesis of hemoglobin $A_{1 c}$. FEBS Lett 71: $356-360$

18. Christiansen JS (1984) On the pathogenesis of the increased glomerular filtration rate in short-term insulin-dependent diabetes. Dan Med Bull 31: 349-361

19. Hostetter TH, Troy JL, Brenner BM (1981) Glomerular hemodynamics in experimental diabetes mellitus. Kidney Int 19: 410-415

20. Wiseman MJ, Saunders AJ, Keen H, Viberti GC (1985) Effect of blood glucose control on increased glomerular filtration rate and kidney size in insulin-dependent diabetes. N Engl J Med 312: $617-621$

21. van Ballegooie E, de Jong PE, Donker AJM, Sluiter WJ (1984) The effect of continuous subcutaneous insulin infusion on renal function in type I diabetic patients with and without nephropathy. In: Davison AM, Guillou PJ (eds) Proc EDTA-ERA 21: 722-724

22. Bosch JP, Glabman S, Lew S, Lauer A (1985) Diabetic nephropathy (DN): response to protein loading. Kidney Int 27: 241

23. Goldberg LJ (1972) Cardiovascular and renal actions of dopamine: potential clinical applications. Pharm Rev 24:1-29

24. Alvestrand A, Bergström J (1984) Glomerular hyperfiltration after protein ingestion, during glucagon infusion, and in insulin-dependent diabetes is induced by a liver hormone. Lancet 1: 195-197

25. Uranga J (1969) The hepatic production of a glomerular pressure substance in the toad (Bufo Arenarum). Gen Comp Endocrinol 13: $179-184$

26. Uranga J (1973) Effect of glomerulopressin, oxytocin, and norepinephrine on glomerular pressure in the toad. Gen Comp Endocrinol 20: 515-521

27. Zatz R, Meyer TW, Noddin JL, Nunn AW, Troy JL, Brenner BM (1984) Dietary protein restriction limits glomerular hyperfiltration in experimental diabetes. Kidney Int 25: 255

28. ter Wee PM, Geerlings W, Rosman JB, Sluiter WJ, van der Geest S, Donker AJM (1985) Testing renal reserve filtration capacity with an amino acid solution. Nephron 41: 193-199

29. Tucker BJ, Blantz RC (1977) Factors determining superficial nephron filtration in the mature growing rat. Am J Physiol 232 F97-F104

Received: 13 February 1985

and in revised form: 2 December 1985

Dr. P.M.ter Wee

Department of Medicine

University Hospital Groningen

59 Oostersingel

NL-9713 EZ Groningen

The Netherlands 